\title{
FEATURES OF IT MARKET DEVELOPMENT IN UKRAINE
}

\section{ОСОБЛИВОСТІ РОЗВИТКУ РИНКУ ІТ-ПОСЛУГ В УКРАЇНІ}

\section{Yana Oleksenko ${ }^{1}$ \\ Serhii Makarenko²}

\section{DOI: https://doi.org/10.30525/978-9934-588-38-9-31}

Abstract. The purpose of the article is to study peculiarities of the functioning and forecast the further development of the IT services market in Ukraine. The methodological basis of the research was made by the scientific works of domestic, foreign scientists and leading experts, statistical and analytical materials of public authorities. As a method of data collection for the research the questionnaire was chosen. The survey was conducted among top executives of higher education institutions (Kherson State University, Kherson National Technical University), local state executive bodies (Department of Economic and Regional Development of Kherson Regional State Administration; Department of Investment and Industrial Policy of Kherson Regional State Administration), trade union organizations (Kherson regional inter-branch council of trade unions). The results were obtained by using such methods as: expert - to study the impact of market factors and resource potential on the competitiveness of IT-enterprises; economic and mathematical - when calculating the forecasting trends in the development of the IT services market; abstract-logical - for theoretical generalization and formulation of conclusions. The article considers the current state of the domestic information technology indus-try. It is shown that the do-mestic market of information technologies is at the stage of active formation. An analysis of Ukrainian IT market was made based on statistical data. This analysis showed that there is great potential for development of innovations sector in Ukraine. A correlation and regression analysis determined two factors that influence the Ukrain-ian IT market the most.

${ }^{1} \mathrm{PhD}$ student of Economics and International Economic Relations Department,

Kherson State University, Ukraine

${ }^{2}$ Candidate of Economic Sciences, Associate Professor,

Assistant Lecturer at Department of Management and Administration,

Kherson State University, Ukraine 
The key factor for the development of the IT sector are qualified personnel. The factors con-straining the development of the IT sector are identified. These include the low avail-ability of state-of-the-art technologies, the low level of government procurement of goods and services in the IT sector, high tax rates, ineffective promotion of the IT sector in the international arena, and low levels of protection of intellectual property rights. Established the main obstacles on the part of the state. It was noted that the state should become a major player in the development of a promising IT industry. It is necessary to form a state strategy of interaction with the IT sector. The mechanism for determining the coefficient of competence of experts involved in assessing the competitiveness of the personal, taking into account their qualitative and quantitative characteristics, deserves further study. This will maximize the effectiveness of the rating assessment and coordinate efforts and re-sources to improve the indicators identified.

\section{1. Ветуп}

У сучасних умовах розвитку економіки України вагомим резервом прискорення економічного зростання та зміцнення конкурентоспроможності національної та регіональної економіки є забезпечення розвитку інформаційного суспільства та IT-галузі зокрема. Подальший розвиток вітчизняної IT-сфери забезпечить перманентне досягнення макроекономічних ефектів, які мають позитивний вплив на соціально-економічний розвиток, що, у разі підсилення у середньостроковій перспективі, може зумовити якісні структурні зміни та модернізацію національного господарства, перетворення IT-індустрії на потужну «точку зростання» національної економіки. Водночас, забезпечення розвитку ІТ-галузі потребує значних фінансових вкладень як 3 державного та місцевих бюджетів, так і від приватних суб'єктів господарювання.

Проведені дослідження [9] стосовно визначення елементів творення сучасного іміджу держави свідчать про наступне:

- понад 100 представників списку найуспішніших компаній світу «Fortune 500»є лояльними клієнтами до вітчизняного IT-бізнесу;

- провідна міжнародна організація Global Sourcing Association відзначила Україну у якості найкращої країни-постачальниці IT-послуг до Великої Британії; 
- авторитетний американський бізнес-журнал Inc. включає українські компаній до переліків таких, що розвиваються найбільш динамічно.

Також встановлено, що останніми роками IT-сфера в Україні є однією 3 найприбутковіших та швидкозростаючих сфер економічної діяльності, яка, за оцінками Світового Банку, міжнародних консалтингових компаній та вітчизняної IT-спільноти, демонструє щорічне зростання не менш ніж на 25\%. Збереження такої тенденції прогнозується як мінімум у короткостроковій перспективі і може суттєво прискорити вихід вітчизняної економіки зі стану глибокої економічної кризи [8, с. 181].

Вказане свідчить про значний потенціал зростання IT-галузі та обумовлює необхідність подальших детальних досліджень тенденцій розвитку українського ринку комп'ютерного програмування, консультування та надання інформаційних послуг. Зазначене визначило актуальність теми дослідження, ії завдання та зміст.

Питанням розвитку інформаційних технологій та їх впливу на економіку України присвячені праці багатьох вітчизняних та зарубіжних учених, зокрема К. Васюка [1], С. Войтко, О. Кулинича [3], В. Волошина, А. Шехловича [4], О. Полякова, О. Ромащенко [8], С. Сисоєва [10], Н. Тимошенко [11], Р. Яремчука, О. Коломієць [13], дані аналітичних агентств [9] та матеріали досліджень за ініціативи Асоціації «IT Ukraine» [6] та багатьох інших.

Економічні проблеми ІТ-підприємств, особливості розвитку ринку IT-послуг, формування конкурентних переваг компаній розглядаються в ро-ботах Р. Винничук, Т. Склярук [2], Н. Мешко, М. Костюченко [7], В. Чижова [12] та ін.

Однак, не зменшуючи цінності перелічених праць, проведений аналіз публікацій свідчить, що на даний час невирішеними залишаються ряд питань, які стосуються особливостей функціонування та прогнозування подальшого розвитку ІТ-підприємств на території України, вивчення основних проблем, що стримують розвиток галузі, формування напрямів руху та можливостей інтеграції на світовому IT-просторі.

Мета дослідження полягає у визначенні основних тенденцій та прогнозуванні подальшого розвитку ринку IT-послуг в Україні.

Методологічну основу дослідження склали наукові праці вітчизняних, зарубіжних вчених та провідних фахівців, статистичні й аналітичні матеріали органів державної влади. Як метод збору даних для 
дослідження було обрано анкету. Анкетування проводилось серед топ-керівництва закладів вищої освіти (Херсонський державний університет, Херсонський національний технічний університет), місцевих органів державної виконавчої влади (Департамент економічного та регіонального розвитку Херсонської обласної державної адміністрації; Департамент інвестиційної та промислової політики Херсонської обласної державної адміністрації), профспілкових організацій (Херсонська обласна міжгалузева рада професійних спілок). Результати отримані шляхом використання таких методів, як: експертний для дослідження впливу ринкових факторів і ресурсного потенціалу на конкурентоспроможність підприємств ринку ІТ-послуг; економіко-математичний - при прогнозуванні тенденцій розвитку ринку IT-послуг; абстрактно-логічний - для теоретичного узагальнення та формулювання висновків; статистичного аналізу - для групування й оцінки економічних явищ і процесів у господарській діяльності IT-підприємств.

\section{2. Особливості функціонування вітчизняної IT-галузі}

Ландшафт ІТ-галузі в Україні є різноманітним, існуючі компанії пропо-нують широкий спектр послуг з комп'ютерного програмування, консультування та надання інших інформаційних послуг. У цілому IT-індустрія складається 3 трьох основних напрямів: IT-аутсорсинг (послуги), розроблення готового програмного забезпечення та виготовлення комп'ютерів й іншого технічного обладнання.

IT-сектор має кілька підсекторів: зокрема, це компанії, що надають тех-нологічні послуги, продуктові компанії, технологічні стартапи, центри розробки та інші, які перебувають на різних рівнях розвитку й потребують різних рішень для подальшого зростання (рис. 1).

Вітчизняний IT-сектор починав свій розвиток з надання аутсорсингових IT-послуг, а саме зі застосовування простих аутстафінгових моделей (залучення IT-фахівців за договором між компаніями). Наразі в Україні застосовується цілий ряд бізнес-моделей для IT-сектора: від аутстафінгу до готових рішень різного ступеня складності за фіксовану ціну, від послуг для малих компаній, яким потрібен програміст або просте рішення для бізнесу, до цілих команд, які працюють та розробляють інновації для стартапів та великих вітчизняних й міжнародних корпорацій. 


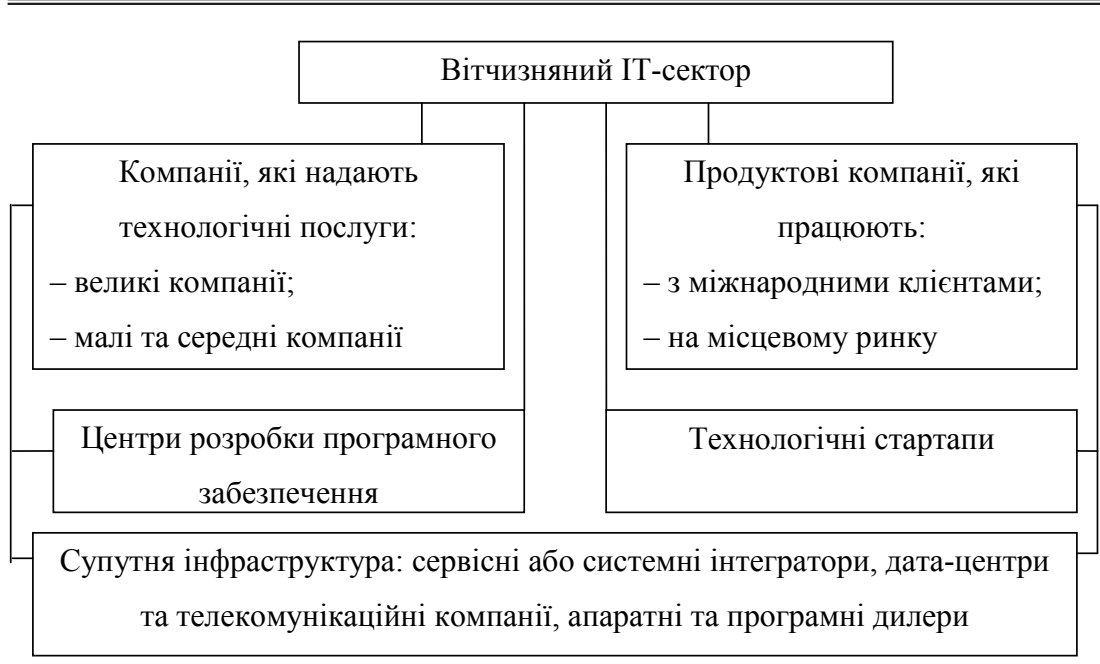

\section{Рис. 1. Структура IT-сектора в Україні}

Джерело: побудовано авторами на основі [6]

Провідні IT-компанії України розробляють складні IT рішення для промисловості, надають консультації з налагодження бізнес-процесів у командах, розробляють високоякісне та складне програмне забезпечення, надають комплексні послуги з розвитку персоналу та змагаються з Microsoft, IBM, Accenture та іншими гігантами галузі за виконання замовлень щодо реалізації великих проєктів для кінцевих клієнтів.

На підставі аналізу теоретичних та практичних джерел $[2 ; 3 ; 7 ; 8 ; 11]$ нами систематизовано основні характеристики підсекторів IT-компаній, які здійснюють свою діяльність на території України:

- великі компанії, які надають технологічні послуги - на сьогодні це найсильніший сегмент. Ці компанії зуміли відійти від простого аутсорсингу до більш масштабних завдань із вагомою доданою вартістю, до яких належать послуги з розширення команд клієнтів (у тому числі послуги з утримання персоналу, тімбілдінгу, програми особистого розвитку, налагодження процесів у команді для оптимальних результатів роботи тощо), а також послуги з надання рішень. Вказані компанії стають усе більш зрілою індустрією інтелектуальних послуг; 
- продуктові компанії, які працюють на міжнародному ринку друга найбільш перспективна група. Із точки зору розвитку сектора $\epsilon$ проблемою той факт, що головний офіс цих компаній розташований поза межами України. За організаційною структурою вказана група не відрізняється від компаній, що надають технологічні послуги, або центрів розробки програмного забезпечення. Водночас, розв'язання проблеми щодо реєстрації головного офісу на території України може допомогти збільшити надходження податків та зборів до бюджетів всіх рівнів від експорту IT-послуг;

- технологічні стартапи - це молоді зірки у відповідності з матрицею Бостонської консалтингової групи, які потребують особливої системи управління для зростання та процвітання. Для стартапів велике значення має державна підтримка, яка може допомогти їм розвиватися у країні і тим самим створювати сприятливе середовище для появи нових об'єктів;

- малі та середні компанії, які надають технологічні послуги - в подальшому можуть стати більш зрілими та продовжити працювати як сервісні компанії або стати продуктовими компаніями. Ці компанії вже активно вивчають можливість трансформації у продуктові компанії через велику конкуренцію в секторі аутсорсингу. Вони потребують підтримки для подальшого зростання в одному із зазначених напрямів. Їх збереження у теперішньому форматі та спроба продовжувати роботу в старій моделі аутсорсингу не матимуть позитивного ефекту для економіки;

- центри розробки програмного забезпечення з функціями дослідження та розробки - вже працюють в Україні. Проте для справжнього впровадження зазначеного напряму кількість центрів необхідно суттєво збільшити. Умови їх діяльності повинні бути переглянуті, щоб збалансувати конкуренцію за ресурси на ринку, а також необхідно надати допомогу в тому, щоб переконати відомі компанії на кшталт Google чи Amazon відкрити свої дослідницькі центри в Україні;

- продуктові компанії, що працюють на місцевому ринку - ця група складається 3 компаній, які акцентують увагу виключно на вітчизняний ринок надання послуг з комп'ютерного програмування, консультування та надання інших інформаційних послуг, і намагаються вижити на досить нерозвиненому локальному ринку. Також до вказаної групи входять і нові 
компанії, що запустили успішні продукти та сервіси на внутрішньому ринку в нішах, які вже зайняті на відповідних зовнішніх ринках;

- системні інтегратори і дата-центри. Інтегратори наразі мають дуже скромний потенціал для експорту. Це також стосується дата-центрів, оскільки вони, незважаючи на свій високий потенціал, працюють розрізнено та не приділяють достатньої уваги пошуку та вирішенню своїх бізнесових проблем, а також недостатньо усвідомлюють сучасні потреби бізнесу.

Україна має перспективи розвитку всіх напрямів, проте найбільшими темпами розвивається саме IT-аутсорсинг. Найбільші гравці ринку IT-аутсорсингу представлені здебільшого філіями міжнародних компаній, а також великими компаніями з центральним офісом в Україні. Ці компанії, як правило, орієнтовані на експорт, з більшою частиною своїх клієнтів у США та частково у Західній Європі. Зокрема, це іноземні «GlobalLogic», «EPAM Systems» (США), «Ciklum» (Данія), «SoftServe», «Infopulse Ukraine» (Україна).

Під час проведення дослідження ринку IT-послуг потрібно враховувати, що продуктові компанії та стартапи зараз не демонструють значного зростання в загальному обсязі експорту послуг, але мають великий потенціал росту в найближчому майбутньому за умови створення сприятливих умов для такого зростання. Такі види IT-послуг, як інтернет речей, робототехніка, хмарні обчислення, штучний інтелект, наука про дані, аналітика великих даних, тривимірний друк та багато інших найновіших трендів в тому чи іншому вигляді вже надаються в Україні, отже, мають бути підсилені шляхом підтримки з боку органів державної влади та місцевого самоврядування.

\section{3. Аналіз потенціалу ринку IT-послуг в Україні}

IT-галузь є однією з найбільш перспективних та інноваційних сфер су-часної економіки України. Основними особливостями українського IT-ринку, що відрізняють його від відповідних ринків економічно розвинених країн, є загальна незрілість, недостатня цивілізованість, непрозорість, широка диверсифікація ринку і послуг, що надаються.

Ми погоджуємося з авторами [4], що, як у 2011-2016 роках, так i станом на сьогодні наявність потенціалу розвитку IT-сфери України підтверджується наступними тенденціями: 
- нарощуванням експортного потенціалу. Обсяг експорту української ІТ-індустрії показує стабільний приріст від 11\% до 26\% щороку, незважаючи на падіння експорту та національної економіки в цілому;

- збільшенням кількості суб'єктів підприємницької діяльності. Наразі важко підрахувати загальну кількість компаній в IT-секторі, оскільки багато IT-компаній, а саме компаній, що надають технологічні послуги, стартапів та продуктових компаній мають свої головні офіси та зареєстровані закордоном. Однак, за даними Асоціації IT в Україні на ринку працює близько 4000 компаній, з них кількість компаній, активних на відповідному сегменті ринку - 2309 од.;

- зростанням кількості зайнятих у ІТ-сфері. Впродовж 2015-2018 pp. кількість зайнятих з урахуванням кількості працівників позаоблікового складу зросла з 74 тис. осіб до майже 160 тис. осіб, тобто щорічно в середньому на 29,3\%. ІТ-індустрія щорічно створює до 15 тис. високооплачуваних робочих місць 3 гідними умовами праці, при цьому створення 1 місця в IT-галузі може стимулювати до створення 3-4 додаткових робочих місць в інших галузях економіки;

- формуванням середнього класу та платоспроможного попиту на внутрішньому ринку. Середньомісячна заробітна плата вітчизняних фахівців, що працюють в IT-галузі, з урахуванням інформації щодо підприємств, які зареєстровані закордоном, складає близько 1600 дол. США або 37,9 тис. грн. (станом на 01 січня 2020 року) на місяць, що у 3,6 разів більше ніж в середньому в Україні (10497 грн). При цьому, високий рівень оплати зберігається не лише в м. Києві, але й в периферійних містах, де працює біля 56\% вітчизняних фахівців у галузі інформаційних технологій, що є чинником забезпечення збалансованого регіонального розвитку;

- розвитком фінансового сектору. ІТ-галузь відіграє важливу роль для економіки України, забезпечуючи надходження до державного бюджету, валютні надходження, робочі місця, доходи для банківського сектора тощо.

Отже, IT-індустрія має величезний потенціал, який наразі перебуває лише на самому початку свого експоненціального зростання. Ефективні ініціативи та дієва підтримка $з$ боку державного та приватного секторів дозволять створити потужну систему управління та укріпити позиції не лише на вітчизняному, а й на глобальному ринках. Водно- 
час останніми роками національний ринок інформаційних технологій розвивався досить хаотично. Численні кадрові, адміністративні, законодавчі реформи не давали можливості IT-галузі активно розвиватися, а специфіка ринку інформаційних технологій полягала в тому, що він був саморегульованим, й держава не створювала сприятливих умов для його розвитку та ефективного функціонування.

Ще однією великою проблемою вітчизняної IT-галузі $є$ незбалансованість ринку. 3 одного боку, щорічно зростає дефіцит висококваліфікованих кадрів, а також стабільно зростає заробітна плата, 3 іншого - існує надлишок фахівців із недостатнім рівнем кваліфікації, внаслідок чого посилюється конкуренція між компаніями за висококваліфіковані людські ресурси, адже кваліфіковані співробітники - вагоме джерело конкурентних переваг та рушійна сила розвитку IT-індустрії $[11$, c. 386$]$.

Основні перешкоди, що стримують розвиток ІТ-галузі в Україні, відображено у таблиці 1.

Усі вищеперераховані чинники негативно впливають на розвиток вітчизняної IT-галузі, однак шляхи вирішення цих проблем все ж таки існують. Передусім, необхідно створити сприятливі умови для роботи висококваліфікованих фахівців та вживати заходів щодо запобігання відтоку кваліфікованих кадрів закордон. Зниження податкового тиску та зменшення бюрократизації, що нині запроваджено для IT-підприємців, частково сприяє активізації діяльності з розроблення вітчизняного програмного забезпечення, однак не дає фахівцям упевненості в майбутньому, адже відбуваються регулярні зміни у чинному законодавстві $[11$, c. 387$]$.

Потрібно враховувати, що українські IT-компанії отримали визнання завдяки своїм висококваліфікованим фахівцям та талантам, їх сильній технічній освіті та конкурентоспроможній вартості їх праці. Україна стала однією з провідних країн за обсягами та капіталізацією ринків у Східній Європі у секторі послуг, які надаються компаніями, що виконують технологічні послуги (TSC) [13, с. 70].

Великі глобальні компанії довіряють українським провайдерам обслуговування своїх IT-процесів та проєктів. Такими компаніями є, зокрема, Microsoft, Oracle, Panasonic, Intel, Ericsson та інші. Проте за повноцінне визнання українських компаній ще слід поборотися, 
Таблиця 1

Основні перешкоди, що стримують розвиток IT-галузі в Україні

\begin{tabular}{|c|c|}
\hline IT-сфера & Людський капітал \\
\hline $\begin{array}{l}\text { - низька конкурентоспроможність в } \\
\text { порівнянні з західними компаніями; } \\
\text { - втрата позицій конкурентоздатності } \\
\text { на світовому ринку; } \\
\text { - нерозвиненість внутрішнього } \\
\text { ІТ-ринку; } \\
\text { - міграція ІТ-компаній зі Сходу } \\
\text { краї-ни, підвищення конкуренції за } \\
\text { людські ресурси. }\end{array}$ & $\begin{array}{l}\text { - кваліфіковані IT-спеціалісти, які не } \\
\text { займаються саморозвитком; } \\
\text { - жорстка конкуренція на IT-ринку } \\
\text { праці: попит перевищує пропози-цію; } \\
\text { - відтік висококваліфікованих кадрів } \\
\text { закордон; } \\
\text { - низький рівень володіння } \\
\text { англійською мовою у IT-фахівців; } \\
\text { - низька якість освіти та підготовки } \\
\text { ІТ-фахівців }\end{array}$ \\
\hline Фінанси та економічний стан & Загальнонаціональні проблеми \\
\hline $\begin{array}{l}\text { - несприятливий бізнес-клімат; } \\
\text { - низький рівень залучених іноземних } \\
\text { інвестицій у розвиток галузі; } \\
\text { - високий рівень корупції; } \\
\text { - низький розвиток інноваційних } \\
\text { галузей в Україні та низький попит на } \\
\text { IТ-послуги. }\end{array}$ & $\begin{array}{l}\text { - військовий конфлікт на сході України; } \\
\text { - інерція бюрократичного апарату: } \\
\text { опір до реформ; } \\
\text { - недорозвиненість ІТ законодавства } \\
\text { України та його невідповідність } \\
\text { світовим та європейським стандартам; } \\
\text { - повільне впровадження в дію змін до } \\
\text { податкового законодавства; } \\
\text { - тимчасова втрата Криму та частини } \\
\text { Донбасу }\end{array}$ \\
\hline
\end{tabular}

Джерело: складено авторами на основі [4; 6; 9]

оскільки частка українських IT-послуг на світовому ринку складає лише біля $1 \%$.

Складний бізнес-клімат, упереджене сприйняття та необізнаність іноземних інвесторів про потенціал розвитку IT-індустрії в Україні, яка насправді охоплює всі перспективні сегменти ринку IT-послуг відповідно до глобальних трендів, заважають залученню капіталу, відкриттю головних офісів IT-компаній в Україні та присутності міжнародних експертів та глобальних компаній, які б могли сприяти подальшому розширенню й розвитку IT-галузі. Надання підтримки IT-компаніям у сферах реклами, маркетингу та продажів, а також розвиток навичок та спроможності IT-фахівців допоможуть покращити загальну ефективність індустрії, а також розширити іiі частку на світовому ринку. Пріоритетне значення для сприяння подальшому розвитку IT-індустрії мають такі ключові кроки: створення сприятливої екосистеми для біз- 
несу, усунення бар'єрів та приведення до сучасних стандартів законодавства, яке повинно допомагати розвитку великих компаній, що надають технологічні послуги, та продуктових компаній, що продають свої послуги й продукти в Україні та на міжнародному ринку; допомога у розвитку технологічних стартапів, малих та середніх компаній, що надають технологічні послуги, і продуктових компаній; підтримка IT-індустрії у підвищенні доданої вартості її продуктів та сприяння створенню інтелектуальної власності в країні; забезпечення висококваліфікованих фахівців практичними навичками на ранніх етапах здобуття вищої освіти та надання доступних програм з вивчення найновітніших IT-технологій для задоволення зростаючого ринкового попиту.

\section{4. Прогнозні тенденції розвитку ринку IT-послуг}

При побудові прогнозних сценаріїв необхідно дослідити найбільш впливові фактори, що впливають на розвиток вітчизняного ринку ІТ-послуг. Використовуючи знання й досвід провідних експертів закладів вищої освіти (Херсонський державний університет, Херсонський національний технічний університет), місцевих органів державної виконавчої влади (Департамент економічного та регіонального розвитку Херсонської обласної державної адміністрації; Департамент інвестиційної та промислової політики Херсонської обласної державної адміністрації), профспілкових організацій (Херсонська обласна міжгалузева рада професійних спілок) було досліджено вплив основних показників на обсяг реалізованих послуг з комп'ютерного програмування, консультування та надання інформаційних послуг (Y). За поглядами респондентів установлено, що найбільший вплив мають наступні показники: обсяги приросту прямих інвестицій (акціонерного капіталу) $\left(\mathrm{X}_{1}\right)$, експорту послуг $\left(\mathrm{X}_{2}\right)$, середньомісячний розмір заробітної плати $\left(\mathrm{X}_{3}\right)$, середньооблікова кількість штатних працівників $\left(\mathrm{X}_{4}\right)$, відпрацьований робочий час $\left(\mathrm{X}_{5}\right)$.

Необхідні матеріали для подальшого оброблення та визначення достовірності й обгрунтованості побудови прогнозної моделі розвитку відображено в таблиці 2.

Використовуючи формулу для обчислення коефіцієнтів парної кореляції, було встановлено наступний зв'язок між результативним показником (Y) та вказаними чинниками: 
Таблиця 2

Необхідні матеріали для подальшого оброблення

та визначення достовірності й обгрунтованості побудови прогнозної моделі розвитку

\begin{tabular}{|c|c|c|c|c|c|c|}
\hline Квартали & 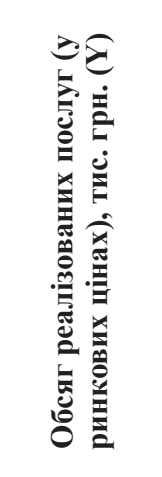 & 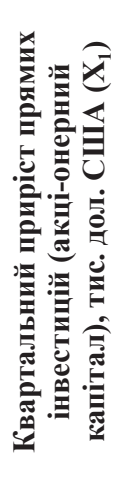 & 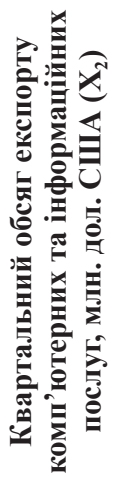 & 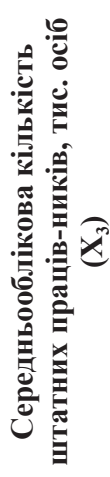 & 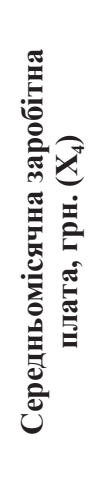 & 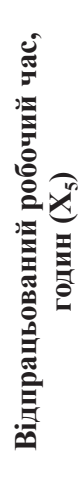 \\
\hline IV квартал 2017 року & 11600857,4 & 1283,5 & 443,5 & 41,2 & 13199 & 446 \\
\hline I квартал 2018 року & 12026731,9 & 12920,3 & 450,8 & 45,2 & 13101 & 451 \\
\hline II квартал 2018 року & 12475661,7 & 369,6 & 477,4 & 44,1 & 14560 & 456 \\
\hline III квартал 2018 року & 13152811,8 & $-2647,4$ & 483,7 & 43,6 & 14282 & 433 \\
\hline IV квартал 2018 року & 14927497,4 & 625,5 & 545,2 & 43,0 & 15212 & 460 \\
\hline I квартал 2019 року & 15410976,2 & 1848,1 & 528,2 & 45,8 & 16362 & 446 \\
\hline II квартал 2019 року & 15534582,1 & 3079,4 & 551,5 & 44,2 & 18422 & 457 \\
\hline III квартал 2019 року & 15798907,8 & 7978,8 & 544,6 & 41,6 & 17199 & 489 \\
\hline
\end{tabular}

Джерело: складено та розраховано авторами на основі [5]

- $\mathrm{r}_{\mathrm{yx1}}=-0,02028-\mathrm{y}$ відповідності зі шкалою оцінювання зв'язку змінних, зв'язок між $\mathrm{Y}$ та $\mathrm{X}_{1}$ майже відсутній, а отже вплив вказаного чинника на кінцевий результат $є$ несуттєвим і до моделі вказаний показник не повинен включатися;

$-\mathrm{r}_{\mathrm{yх2}}=0,000056-$ зв'язок між $\mathrm{Y}$ та $\mathrm{X}_{2}$ відсутній;

$-\mathrm{r}_{\mathrm{yх3}}=0,08693-$ зв'язок між $\mathrm{Y}$ та $\mathrm{X}_{3}$ майже відсутній;

$-\mathrm{r}_{\mathrm{yx4}}=0,91028$ - зв'язок між $\mathrm{Y}$ та $\mathrm{X}_{4}$ вважається дуже високим;

$-\mathrm{r}_{\mathrm{yx} 5}=0,52052$ - зв'язок між $\mathrm{Y}$ та $\mathrm{X}_{5}$ вважається вище середнього.

Таким чином, розрахунок коефіціснтів парної кореляції дозволив виявити суттєві і несуттєві фактори впливу на результативний показник. Фактори $\mathrm{X}_{1}, \mathrm{X}_{2}$ та $\mathrm{X}_{3}$ по цьому критерію в подальшому не розглядаються $\mathrm{i}$ 
до моделі не включаються, що дозволяє в деякій мірі спростити розрахунки без суттєвих спотворень результатів моделювання й прогнозування.

Однією із умов доцільності використання побудованої економетрічної моделі є перевірка наявності мультіколінеарності. Використовуючи формулу для обчислення коефіцієнтів парної кореляції, було встановлено наступний зв'язок між показниками $\mathrm{X}_{4}$ та $\mathrm{X}_{5}$ :

$-\mathrm{r}_{\mathrm{x} 4 \times 5}=0,5093-$ знаходиться у проміжках норми.

Отже, взаємозв'язок між факторами $\mathrm{X}_{4}$ та $\mathrm{X}_{5}$ знаходиться на середньому рівні, тобто у проміжках норми.

Однією із вимог при побудові економетрічної моделі є розрахунок коефіцієнту автокореляції між рівнями обсягу реалізованих послуг (у ринкових цінах). Використовуючи формулу для обчислення коефіцієнту автокореляції було встановлено наступне:

$-\mathrm{r}_{\mathrm{y}}=0,76717$ - отже $є$ в наявності достатньо сильна лінійна тенденція.

Враховуючи результати проведених розрахунків при прогнозуванні обсягу реалізованих послуг з комп'ютерного програмування, консультування та надання інформаційних послуг в Україні будемо використовувати наступну множинну лінійну регресію:

$$
\mathrm{Y}=\mathrm{A}_{0}+\mathrm{A}_{1} * \mathrm{X}_{1}+\mathrm{A}_{2} *
$$

де $\mathrm{Y}$ - обсяг реалізованих послуг 3 комп’ютерного програмування, консультування та надання інформаційних послуг (у ринкових цінах), тис. грн;

$\mathrm{X}_{1}$ - середньомісячна заробітна плата в IT-галузі, грн.;

$\mathrm{X}_{2}-$ відпрацьований робочий час, год.

За результатами проведених розрахунків отримано наступну функцію:

$$
\mathrm{Y}=-1987566,84+793,1241579 * \mathrm{X}_{1}+8191,349894 * \mathrm{X}_{2}
$$

Для встановлення достовірності побудованої економетрічної моделі проведено розрахунок коефіцієнту детермінації $\left(\mathrm{R}^{2}\right)$

$$
\mathrm{R}^{2}=0,83299
$$

Чим ближче значення коефіцієнту детермінації до одиниці, тим сильніша лінійна залежність. Так як $\mathrm{R}^{2}$ дорівнює 0,83299 можемо стверджувати, що економетрічна модель побудована достовірно.

Розрахуємо значення коефіцієнту множинної кореляції (r)

$$
\mathrm{r}=\sqrt{0,83299}=0,91268
$$


Так як числове значення коефіціснту множинної кореляції більше значення любого із парних коефіцієнтів кореляції, а також не перевищує одиниці, можна робити висновок о достовірності побудови економіко-математичної моделі, що характеризує вітчизняний ринок IT-послуг. Отримані результати відобразимо на рис. 2.

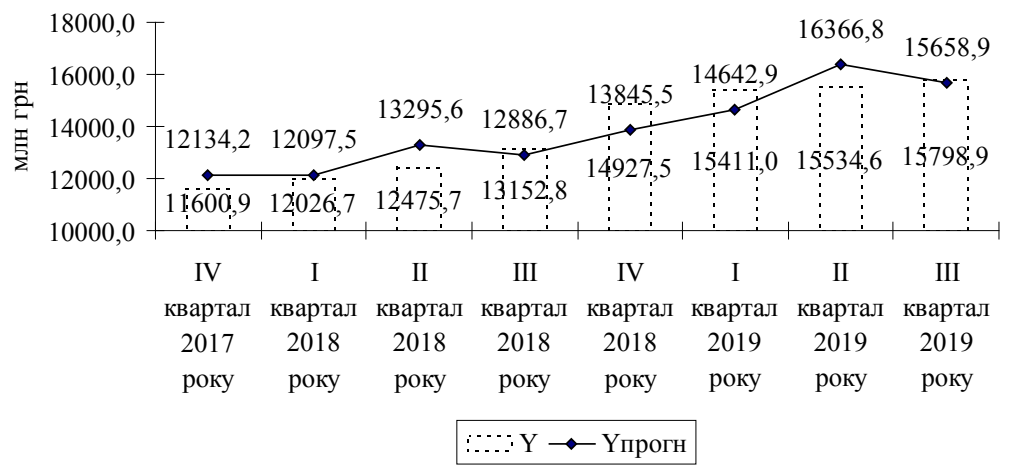

\section{Рис. 2. Побудова моделі, що характеризує вітчизняний ринок IT-послуг}

Джерело: побудовано авторами

Для встановлення впливу факторів $\mathrm{X}_{1}$ та $\mathrm{X}_{2}$ на результативний показник Y проведемо розрахунок коефіцієнтів еластичності, використовуючи наступну формулу:

$$
\mathrm{E}_{\mathrm{yx}}=\mathrm{A}_{\mathrm{j}} * \frac{\sum_{\mathrm{i}=1}^{\mathrm{n}} \mathrm{X}_{\mathrm{j} . \mathrm{i}}}{\sum_{\mathrm{i}=1}^{n} \mathrm{Y}_{\mathrm{i}}}
$$

де $\mathrm{j}$ - порядковий номер фактору;

i - порядковий номер кварталів;

n - кількість кварталів.

$$
\mathrm{E}_{\mathrm{yx}_{1}}=793,1241579 * \frac{122337}{110928026,3}=0,8747
$$

Коефіцієнт еластичності по першому фактору дорівнює 0,8747 , що свідчить про достатній вплив середньомісячної заробітної плати в 
IT-галузі на обсяг реалізованих послуг з комп’ютерного програмування, консультування та надання інформаційних послуг.

$$
\mathrm{E}_{\mathrm{yx}_{2}}=8191,349894 * \frac{3638}{110928026,3}=0,26864
$$

Коефіцієнт еластичності по другому фактору дорівнює 0,26864, що свідчить про невеликий вплив відпрацьованого робочого часу на обсяг реалізованих послуг з комп'ютерного програмування, консультування та надання інформаційних послуг.

Для оцінки рівня впливу кожного із факторів, включених в економетричну модель, на формування результативного показника - обсягу реалізованих послуг з комп'ютерного програмування, консультування та надання інформаційних послуг, скористаємося методом ланцюгових підстановок. Тобто, змінимо чисельне значення кожного фактору змінних на $10 \%$ і порівняємо отримані результати з результатом в останньому часовому періоді.

Отже, відповідно до побудованої економіко-математичної моделі, розрахуємо математичний обсяг реалізованих послуг в останньому часовому періоді:

$$
\begin{gathered}
Y_{\text {ост }}=-1987566,84+793,1241579 * X_{1}+8191,349894 * X_{2}= \\
=-1987566,84+793,1241579 * 17199+8191,349894 * 489= \\
15658945,65 \text { (тис. грн.) }
\end{gathered}
$$

Збільшимо кожний фактор почергово на 10\%:

$$
\begin{gathered}
\mathrm{Y}_{1}=-1987566,84+793,1241579 * 17199 * 1,1+8191,349894 * 489= \\
=17023039,89 \text { (тис. грн.) }
\end{gathered}
$$$$
\mathrm{Y}_{2}=-1987566,84+793,1241579 * 17199 * 1,1+8191,349894 * 489 * 1,1=
$$$$
=17423596,9 \text { (тис. грн.) }
$$

Порівняємо кожний наступний результат з попереднім:

$$
\begin{gathered}
\Delta_{1}=17023039,89-15658945,65=1364094,24 \text { (тис. грн.) } \\
\Delta_{2}=17423596,9-17023039,89=400557,01 \text { (тис. грн.) }
\end{gathered}
$$

Результати проведеного дослідження показують, що у короткостроковому періоді, при відсутності джерел фінансування для розвитку ринку ІТ-послуг, суттєвий вплив на обсяг реалізованих послуг 3 
комп'ютерного програмування, консультування та надання інформаційних послуг оказує розмір середньомісячної заробітної плати. Отже, топ-керівництву вітчизняних IT-підприємств необхідно першочергово забезпечити розроблення дієвої системи мотивації працівників для ефективного виконання функціональних обов'язків та подальшого самовдосконалення шляхом запровадження обгрунтованого методичного підходу до оцінювання кількісних та якісних показників діяльності.

\section{5. Аналіз сучасних підходів до оцінювання персоналу IT-підприсмств}

Оцінка конкурентоспроможності працівників - цілеспрямований процес встановлення відповідності професійних і особистих характеристик (компетенцій) співробітників вимогам посади та їх відповідність розміру заробітної плати за допомогою визначених критеріїв. На підставі оцінки вирішуються наступні задачі: визначення функціональної ролі працівника у виробничому процесі та місця в організаційній структурі підприємства; розробка комплексу заходів щодо підвищення кваліфікаційних характеристик працівника; визначення відповідності ефективності діяльності працівника та виробничої дисципліни встановленому розміру оплати праці. Оцінка може допомогти у встановленні зворотнього зв'язку між співробітником та керівництвом суб'єкта господарювання в оцінці власної праці та визначенні ключових напрямів саморозвитку [15].

Раніше проведені дослідження $[14 ; 16]$ свідчать, що головним питанням оцінки кваліфікаційної відповідності працівників підприємства вимогам ринку трудових ресурсів є встановлення показників оцінки, що можуть характеризувати як загальні моменти, рівноцінні для всіх працівників підприємства (приналежність співробітника до конкретної організаційної, соціально-культурної системи), так і норми праці для конкретного робочого місця або посади (відповідність кваліфікації працівника встановленим професійним вимогам). Проведення оцінки конкурентоспроможності персоналу дозволить виявити співробітників, обсяг функціональних обов'язків яких нижчий за встановлений розмір заробітної плати. Зазначене дозволить скоротити загальний обсяг фонду оплати праці без скорочення обсягів виробленої продукції, виконаних робіт, наданих послуг. 
Щоб оцінити внесок кожного працівника у збільшення обсягів наданих послуг доцільно використовувати методики, побудовані на проведенні експертного оцінювання групою залучених фахівців, та розрахунку інтегрованого показника конкурентоспроможності. Водночас потрібно враховувати, що не завжди працівники, які мають найвищий рівень кваліфікаційної компетентності та оптимальне співвідношення між обсягом, якістю виконаних функціональних обов'язків і розміром нарахованої заробітної плати, мають позитивний вплив на загальне зростання рівня конкурентоспроможності підприємства. Так, на прикладі провідного ІТ-підприємства, що функціонує у м. Херсон (Херсонська область, Україна), використовуючи метод таксономічного аналізу, за визначеною сукупністю показників оцінювання (рівень освіти; рівень володіння іноземною мовою; загальний стаж роботи за спеціальністю; стаж роботи на підприємстві; кількість внесених раціональних пропозицій; кількість виробничих конфліктів; розмір середньомісячної заробітної плати) було встановлено, що найвищий рівень конкурентоспроможності за підсумками 2019 року має працівник №7. Також зазначений працівник $є$ найбільш цінним для керівництва досліджуваного ІТ-підприємства як за якісними складовими, так і за витратами на його утримання. Водночас, зазначена особа $є$ конфліктною і за кількістю виробничих конфліктів має найгірше значення у досліджуваному структурному підрозділі, що в подальшому може негативно вплинути на рівень взаємодії та згуртованості у колективі.

Враховуючи, що найкращою моделлю функціонування підприємства $є$ робота персоналу як єдиної команди зі спільними цінностями, нормами і правилами поведінки, додатково було досліджено рівень зміни конкурентоспроможності вищевказаного ІТ-підприємства в 2019 році у порівнянні з 2017 та 2018 роками. Розрахований інтегральний показник конкурентоспроможності досліджуваного IT-підприємства у 2017-2019 роках відображено на рис. 3.

За результатами проведеного дослідження встановлено, що конкурентоспроможність досліджуваного підприємства протягом 2017-2019 років суттєва знизилася. Зазначене пов'язано як зі зниженням рівня рентабельності реалізованих послуг, так і зі зростанням коефіцієнту плинності кадрів та зниженням продуктивності праці. 


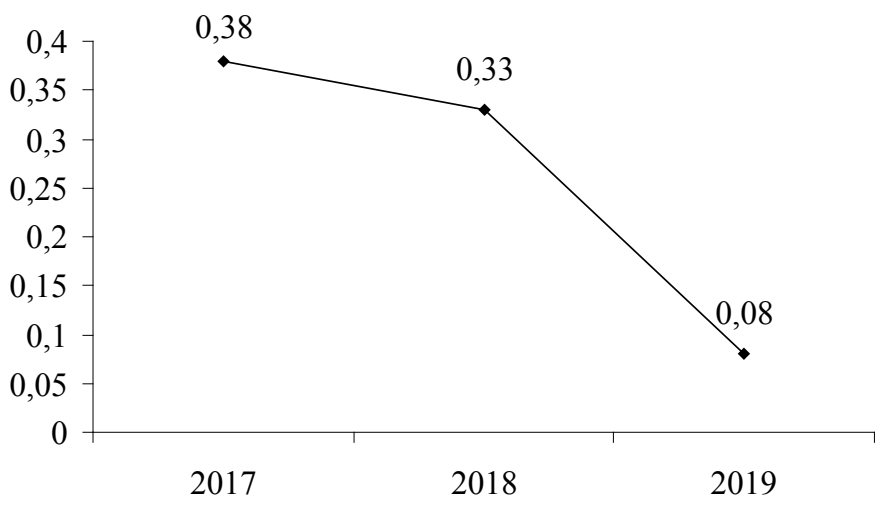

\section{Рис. 3. Інтегральний показник конкурентоспроможності досліджуваного IT-підприсмства за 2017-2019 роки}

Джерело: побудовано авторами

\section{6. Висновки $з$ проведеного дослідження}

Результати проведеного дослідження свідчать, що ІТ-галузь $є$ однією з найбільш перспективних та інноваційних сфер сучасної економіки України. Основними особливостями українського IT-ринку, що відрізняють його від аналогічних ринків економічно розвинених країн, $є$ загальна незрілість, недостатня цивілізованість, непрозорість, широка диверсифікація ринку і моделей, що надаються. Встановлено, що Україна має потужний кваліфікаційний потенціал у сфері інформаційних технологій, IT-фахівці з України користуються популярністю у всьому світі.

Виявлено, що у короткостроковому періоді, при відсутності джерел фі-нансування для розвитку ринку IT-послуг, суттєвий вплив на обсяг реалізованих послуг з комп'ютерного програмування, консультування та надання інформаційних послуг має розмір середньомісячної заробітної плати. Отже, топ-керівництву вітчизняних IT-підприємств необхідно першочергово забезпечити розроблення дієвої системи мотивації працівників для ефективного виконання функціональних обов'язків та подальшого самовдосконалення шляхом запровадження обгрунтованого методичного підходу до оцінювання кількісних та якісних показників діяльності. Також необхідно акцентувати увагу на 
формуванні й впровадженні дієвої корпоративної культури із визначеною сукупністю матеріальних і нематеріальних (духовних) цінностей, норм і правил поведінки працівників як по відношенню до клієнтів i партнерів, так і безпосередньо до керівництва, колег, підлеглих на самому підприємстві, установі, організації. Зазначене дозволить мінімізувати виробничі конфлікти, сприятиме згуртованості колективу, що в подальшому призведе до підвищення продуктивності праці та ефективності й конкурентоспроможності підприємств

Заслуговує подальшого дослідження механізм визначення коефіці$є н$ ку компетентності експертів, залучених до визначення питомої ваги факторів при оцінюванні рівня конкурентоспроможності персоналу 3 урахуванням їх досвіду роботи, масштабності управлінської діяльності, рівня освіти.

\section{Список літератури:}

1. Васюк К. Эволюция IT-аутсорсинга в Украине состоялась. 2017. URL: https://www.liga.net/economics/opinion/evolyutsiya-it-autsorsinga-v-ukrainesostoyalas (дата звернення: 23.02.2020).

2. Винничук Р.О., Склярук Т.В. Особливості розвитку IT-ринку в Україні: стан та тенденції. Вісник Національного університету «Львівська політехніка». 2015. № 833. С. 3-8.

3. Войтко С.В., Кулинич О.О. Напрями розвитку ІКТ-сфери у забезпеченні належного рівня конкурентоспроможності на міжнародному ринку IT-послуг. Економіка. Управління. Інноващіï. 2014. № 1. URL: http://ktpu.kpi.ua/wp-content/ uploads/2016/02/07-eui_2014_1_60.pdf (дата звернення: 23.02.2020).

4. Волошин В.І., Шехлович А.М. Фінансово-економічні інструменти стимулювання розвитку IT-сфери України. Аналітична записка. 2017. URL: https://niss.gov.ua/doslidzhennya/ekonomika/finansovo-ekonomichni-instrumentistimulyuvannya-rozvitku-it-sferi-ukraini (дата звернення: 23.02.2020).

5. Державна служба статистики України. URL: http://www.ukrstat.gov.ua (дата звернення: 23.02.2020).

6. Експортна стратегія України. Дослідження щодо секторальної стратегії розвитку інформаційно-комунікаційних технологій 2019-2023. Проєкт. URL: http://www.me.gov.ua/Documents/Download?id=798fe949-f5fc-473b-8909ed6217264dd9 (дата звернення: 23.02.2020).

7. Мешко Н.П., Костюченко М.К. Перспективи розвитку сфери IT як провідної інноваційної галузі України. Вісник Дніпропетровського університету. Серія Менеджмент інноващій. 2015. Вип. 4. С. 71-77.

8. Полякова О.М., Ромащенко О.В. Сучасні тенденції розвитку IT-індустрії в Україні і світі. Вісник економіки транспорту i промисловості. 2018. № 64. C. 179-186. 
9. Розвиток української ІТ-індустрії: аналітичний звіт. Київ, 2018. URL: https://brdo.com.ua/wp-content/uploads/2018/12/IT_report_ua_F-1.pdf (дата звернення: 23.02.2020).

10. Сисоєв Є. Стратегічний національний проект «Інноваційна Україна». 2014. URL: https://www.slideshare.net/YevgenSysoyev/ss-32717561

11. Тимошенко Н.Ю., Ронський Б.Ю. Проблеми та перспективи розвитку ІТ-індустрії в Україні. Економіка і суспільство. 2018. № 17. С. 384-388. URL: https://doi.org/10.32782/2524-0072/2018-17-57

12. Чижов В. А. Проблеми та перспективи управління IT-компаніями в умовах соціально-економічної кризи України. Економіка та держава. 2016. № 9. С. 68-71.

13. Яремчук Р.С., Коломієць О.Г. Основні переваги та загрози для комплексного розвитку IT-сектора України від реалізації Угоди про асоціацію 3 ЄС. Сочіально-економічні проблеми сучасного періоду України. 2015. Вип. 5. C. $68-72$.

14. Makarenko S., Oliinyk N., Kazakova T. Improving the Method Approach to the Rating Evaluation of Employees as Professional Career Development. Baltic Journal of Economic Studies. 2018. Vol. 4, No. 5 December, pp. 179-187. doi: 10.30525/2256-0742/2018-4-5-179-187

15. Makarenko S., Oliinyk N., Danko V., Kaplina Y. Formation of an Innovative Competitiveness Management System of the Enterprise: On the Case of Ukraine's Healthcare. Journal of Economics and Management Sciences. 2020. Vol. 3, № 1, pp. 1-12. doi: https://doi.org/10.30560/jems.v3n1p1

16. Tyukhtenko N. A., Makarenko S. M. Economic and mathematic models for staff planning at enterprises of all ownership forms. Actual problems of economics. 2016. Vol. 1, No 175, pp. 435-442.

17. Tyukhtenko N., Makarenko S., Oliinyk N., Gluc K., Portugal Ed., \& Rybachok S. Innovative development of the regions: cooperation between enterprises and state institutions. Marketing and Management of Innovations. 2019. № 3, pp. 354-365. doi: http://doi.org/10.21272/mmi.2019.3-27

\section{References:}

1. Chyzhov V.A. (2016). Problemy ta perspektyvy upravlinnia IT-kompaniiamy $\mathrm{v}$ umovakh sotsialno-ekonomichnoi kryzy Ukrainy [Problems and perspectives of IT companies management under the socio-economic crisis in Ukraine]. Ekonomika ta derzhava, vol. 9, pp. 68-71.

2. Eksportna stratehiia Ukrainy. Doslidzhennia shchodo sektoralnoi stratehii rozvytku informatsiino-komunikatsiinykh tekhnolohii 2019-2023. Proiekt [Export strategy of Ukraine. Research on the sectoral strategy for the development of information and communication technologies 2019-2023. Project]. Available at: http://www.me.gov.ua/Documents/Download?id=798fe949-f5fc-473b-8909ed6217264dd9 (accessed 23.02.2020).

3. Iaremchuk R.Ye., Kolomiiets O.H. (2015). Osnovni perevahy ta zahrozy dlia kompleksnoho rozvytku IT-sektora Ukrainy vid realizatsii Uhody pro asotsiatsiiu z 
YeS [Key benefits and challenges for a comprehensive development of the IT sector in Ukraine of implementing the association agreement with the EU]. Sotsialnoekonomichni problemy suchasnoho periodu Ukrainy, vol. 5, pp. 68-72.

4. Makarenko S., Oliinyk N., Danko V., Kaplina Y. Formation of an Innovative Competitiveness Management System of the Enterprise: On the Case of Ukraine's Healthcare. Journal of Economics and Management Sciences. 2020. Vol. 3, № 1, pp. 1-12. doi: https://doi.org/10.30560/jems.v3n1p1

5. Makarenko S., Oliinyk N., Kazakova T. Improving the Method Approach to the Rating Evaluation of Employees as Professional Career Development. Baltic Journal of Economic Studies. 2018. Vol. 4, No. 5 December, pp. 179-187.

6. Meshko N.P., Kostiuchenko M.K. (2015). Perspektyvy rozvytku sfery IT yak providnoi innovatsiinoi haluzi Ukrainy [Prospects for IT development as a leading innovation industry in Ukraine]. Visnyk Dnipropetrovskoho universytetu. Seriia Menedzhment innovatsii, vol. 4, pp. 71-77.

7. Poliakova O.M., Romashchenko O.V. (2018). Suchasni tendentsii rozvytku IT-industrii v Ukraini i sviti [Modern trends of IT-industry development in Ukraine and in the world]. Visnyk ekonomiky transportu i promyslovosti, vol. 64, pp. 179-186.

8. Rozvytok ukrainskoi IT-industrii: analitychnyi zvit [Development of Ukrainian IT industry: analytical report]. Available at: https://brdo.com.ua/ wp-content/uploads/2018/12/IT_report_ua_F-1.pdf (accessed 23.02.2020).

9. State Statistics Service of Ukraine. Available at: http://www.ukrstat.gov.ua (accessed 23.02.2020).

10. Sysoiev Ye. (2014). Stratehichnyi natsionalnyi proekt «Innovatsiina Ukraina» [Strategic national project «Innovative Ukraine»]. Available at: https://www.slideshare.net/YevgenSysoyev/ss-32717561 (accessed 23.02.2020).

11. Tymoshenko N.Yu., Ronskyi B.Yu. (2018). Problemy ta perspektyvy rozvytku IT-industrii v Ukraini [Problems and prospects of development of the IT-industry in Ukraine]. Ekonomika i Suspilstvo. Mukachivskyi derzhavnyi universytet, vol. 17, pp. 384-388. doi: 10.32782/2524-0072/2018-17-57

12. Tyukhtenko N. A., Makarenko S. M. Economic and mathematic models for staff planning at enterprises of all ownership forms. Actual problems of economics. 2016. Vol. 1, No 175, pp. 435-442.

13. Tyukhtenko N., Makarenko S., Oliinyk N., Gluc K., Portugal Ed., \& Rybachok S. Innovative development of the regions: cooperation between enterprises and state institutions. Marketing and Management of Innovations. 2019. № 3, pp. 354-365. doi: http://doi.org/10.21272/mmi.2019.3-27

14. Vasiuk K. (2017). Evoliutsyia IT-autsorsynha v Ukrayne sostoialas [The evolution of IT-outsourcing in Ukraine took place] Available at: https://www.liga.net/ economics/opinion/evolyutsiya-it-autsorsinga-v-ukraine-sostoyalas (accessed 23.02.2020).

15. Voitko S.V., Kulinich O O. (2014). Napriamy rozvytku IKT-sfery u zabezpechenni nalezhnoho rivnia konkurentospromozhnosti na mizhnarodnomu rynku IT-posluh [Areas of ICT sphere in ensuring proper level of competitiveness in the international market of IT-services]. Ekonomika. Upravlinnia. Innovatsii. Available at: ktpu.kpi.ua/wp-content/uploads/2016/02/07-eui_2014_1_60.pdf (accessed 23.02.2020). 
16. Voloshyn V.I., Shekhlovych A.M. (2017). Finansovo-ekonomichni instrumenty stymuliuvannia rozvytku IT-sfery Ukrainy. Analitychna zapyska [Financial and economic instruments to stimulate the development of the IT-sphere of Ukraine. Analytical note]. Available at: https://niss.gov.ua/doslidzhennya/ekonomika/ finansovo-ekonomichni-instrumenti-stimulyuvannya-rozvitku-it-sferi-ukraini (accessed 23.02.2020).

17. Vynnychuk R.O., Sklyaruk T.V. (2015). Osoblyvosti rozvytku IT-rynku v Ukraini: stan ta tendentsii [Specifics of Ukraine it-market: character and trends]. Visnyk Natsionalnoho universytetu «Lvivska politekhnika», vol. 833, pp. 3-8. 